\title{
Effects of herbivory and nutrients on the early colonization of crustose coralline and fleshy algae
}

\author{
Stephanie A. Belliveau*, Valerie J. Paul \\ Marine Laboratory, University of Guam, UOG Station, Mangilao, Guam 96923, USA
}

\begin{abstract}
The persistence of phase shifts from coral-dominated to macroalgae-dominated communities following disturbances has been largely attributed to reduction of herbivores and eutrophication on tropical coral reefs. The influence of reduced herbivory and increased nutrients and their combined interactions on the colonization of crustose coralline algae (CCA) and fleshy algae onto settlement tiles was studied for effects on community structure. Cages were used to manipulate herbivory, and slowrelease fertilizer was used for nutrient enrichment. The responses of the following variables were measured at 2 adjacent reefs in Guam, Mariana Islands: percentage cover of CCA, fleshy algal biomass, coral recruitment, and sediment load. Fleshy algal biomass and sediment were greatest on tiles where herbivores were excluded, whereas CCA were most abundant on tiles exposed to herbivores. Nutrients did not have a significant effect on fleshy algae; however, CCA had a lower level of increase in response to increased nutrients at 1 site. Coral recruitment was low; therefore, preferential settlement to substratum type was indeterminable. This study demonstrates that herbivory, in particular, can have a marked effect on the initial composition of the benthic community, even over a relatively short time span. Moreover, the inverse relationship between CCA and both fleshy algae and sediment has implications for the recruitment of organisms with reliance on CCA.
\end{abstract}

KEY WORDS: Algae $\cdot$ Coral reefs $\cdot$ Crustose coralline algae $\cdot$ Eutrophication $\cdot$ Herbivory

\section{INTRODUCTION}

The prevailing view among coral reef biologists is that natural disturbances coupled with chronic anthropogenic disturbances are leading to the deterioration of coral reefs worldwide (Hughes 1994, Birkeland 1997a, Connell 1997, Dight \& Scherl 1997, Lapointe 1997). Natural disturbances such as hurricanes, crownof-thorns seastar outbreaks, and disease play a critical role in structuring coral reef ecosystems by maintaining high diversity at intermediate levels of disturbance (Connell 1978, Grigg 1983). Anthropogenic disturbances are on the rise, primarily as a result of population growth, and are increasingly altering what we perceive as 'natural' reef communities (Brown 1997). These anthropogenic disturbances include agricultural

*Present address: 14 Elliot Trail, Grafton, Massachusetts 01519, USA. E-mail: oloves7@hotmail.com run-off, dredging, sewage pollution, industrial development, recreational activities, and fishing (Rogers 1990, Birkeland 1997a). Reef ecosystems are seemingly adapted to some level of natural disturbance and following disturbance will go through transient successional phases resulting in a species composition similar to the pre-disturbance community (Lewontin 1969, Kaehler \& Williams 1997). However, chronic human disturbance presents a threat of permanent change to reef community composition, including compositional shifts in species abundance and diversity (Jackson 1992). Recently, it has been suggested that coral reef communities exist in multiple stable states (after Sutherland 1974), also referred to as alternative stable states or phase shifts (Hatcher 1984, Done 1992, Knowlton 1992, Hughes 1994).

Following disturbances, algae and other opportunistic species colonize open substrata through rapid recruitment (Kaehler \& Williams 1997). The presence of herbi- 
vores can suppress fleshy algae, preventing them from overgrowing corals and crustose coralline algae (CCA) (Steneck 1997), thus promoting successional changes that can lead to a diverse composition of species (Hay 1984, Carpenter 1986, Lewis 1986). A significant reduction in grazing has been shown to halt successional changes in reef community composition, so that turf algae and macroalgae persist, ultimately outcompeting corals and inhibiting recruitment of coral planulae (Birkeland 1977). In Jamaica, hurricanes and the mass mortality of the echinoderm Diadema antillarum, confounded by overfishing, resulted in a phase shift from a coral-dominated to a macroalgae-dominated community (Hughes 1994). Reduced herbivory may be further exacerbated by pollution, which introduces nutrients that can potentially promote algal growth, further endangering the ability of corals to survive (Birkeland 1977, Littler \& Littler 1984, Lapointe et al. 1997, Adey 1998). In Kaneohe Bay, Hawaii, sedimentation and eutrophication were primary causes of a community-level phase shift from a coral-dominated community to one composed primarily of macroalgae and suspension- and filter-feeding organisms (Smith et al. 1981, Hunter \& Evans 1995). Twenty years later the increasing depletion of herbivores and nutrient-rich sediments have been suggested as reasons for the continued abundance of macroalgae in the bay (Stimson et al. 2001).

It appears that many reefs are suffering from both decreased herbivory and increased nutrients (Richmond 1997), and that shifts in community structure may result from a combination of the 2 effects. The Relative Dominance Model (RDM) (Littler \& Littler 1984) predicts changes in benthic coral reef communities as a function of both herbivory and nutrients. While the importance of herbivory in structuring reef communities is well recognized (Carpenter 1986, Lewis 1986, Hay 1991, Steneck \& Dethier 1994, Hixon \& Brostoff 1996), the effect nutrients have on structuring coral reef communities is equivocal (Hatcher \& Larkum1983, Larkum \& Koop 1997, Hughes et al. 1999, Lapointe 1999, McCook 1999, Miller et al. 1999, Aronson \& Precht 2000, Wilder 2000, Smith et al. 2001, Thacker et al. 2001). Bell (1992) and Lapointe (1997) suggested a threshold limit of dissolved nutrients on reefs to be $1.0 \mu \mathrm{M}$ of dissolved inorganic nitrogen (DIN) and 0.1 to $0.2 \mu \mathrm{M}$ of soluble reactive phosphate (SRP), above which eutrophication leads to increased macroalgal growth. Empirical evidence has not supported the hypothesis that exceeding a threshold level of nutrients enhances macroalgal growth (Hatcher \& Larkum 1983, Larkum \& Koop 1997, Szmant 1997, Miller et al. 1999, Thacker et al. 2001). Nutrients can fluctuate widely temporally and spatially, due to such factors as coastal inputs, water flow, biogeochemical fluxes, and nutrient-rich sediments (Steneck \& Dethier 1994,
McCook 1999); therefore, the methods used to measure nutrient levels, e.g. from water-column, sediment, or algal tissue need to be considered.

The colonization of fleshy algae or CCA likely plays a major role in determining whether a shift towards macroalgae or coral domination occurs. CCA are potentially a key factor in structuring species composition. Some species of CCA contain chemical cues that facilitate the settlement and metamorphosis of some coral planulae (Morse \& Morse 1996, Morse et al. 1996, Heyward \& Negri 1999) and octocoral planulae (Lasker \& Kim 1996, Slattery et al.1999); also, bacteria associated with CCA induce settlement of the crown-ofthorns starfish Acanthaster planci (Johnson \& Sutton 1994). The abundance of CCA thus may be a key factor in facilitating recovery of scleractinians. Fleshy algae, on the other hand, compete with CCA and corals, pre-empting settlement and inhibiting coral recruitment (Birkeland 1977). The entrapment of sediment by fleshy algae can also inhibit coral recruitment (Birkeland 1977) and survivorship of CCA (Steneck 1997, Fabricius \& De'ath 2001).

In this study, field experiments manipulating herbivores and nutrients were conducted to better understand their influence on the early colonization of fleshy algae, CCA, coral recruits, and accumulation of sediment to open substratum. We hypothesized that nutrient enrichment would increase the growth of fleshy algae, which would indirectly decrease growth of CCA through competition. We predicted that herbivore exclusion would also have a positive effect on the growth of fleshy algae, negatively affecting growth of CCA, not only by dominating but also due to the entrapment of sediment, which can smother and kill CCA. Thus, we predicted that sediment would increase on tiles that had decreased herbivory and increased nutrients, conditions that favor fleshy algal growth. And finally, we predicted that coral recruits would settle more on substratum dominated by CCA.

\section{MATERIALS AND METHODS}

Study sites. The study was conducted at 2 sites, Piti Bomb Holes and Asan, which are situated on the leeward side of Guam and separated by approximately $2 \mathrm{~km}$. Field manipulations were conducted at a depth of $10 \mathrm{~m}$ on the forereef at each site. Temperature and salinity were measured weekly at both sites using a Water Checker U-10 (Horiba). The average temperature at Piti Bomb Holes was $29.5^{\circ} \mathrm{C}$ and at Asan $29.8^{\circ} \mathrm{C}$; the salinity averaged $34.6 \%$ at Piti and $34.7 \%$ at Asan. The field study began on June 27, 2000, 3 wk before the predicted mass coral spawning, and concluded 5 wk later on August 3, 2000. 
Experimental design. A 3-way factorial design was used to test for the effects of herbivory, nutrients, and site on the initial colonization of CCA and algae and the entrapment of sediment on settlement tiles. Three levels of herbivore exclusion were used: fully caged tiles, partially caged tiles, and uncaged tiles. The partially caged plots were used as cage controls (Steele 1996). The influence nutrients had on colonization was investigated by placing half of the tiles in plots enriched with fertilizer, and the other tiles were set in ambient (unenriched) plots. Each of the 3 herbivore manipulations (caged, uncaged, partially caged) was combined with either nutrient condition (enriched or ambient) for a total of 6 treatment possibilities. Each of the 6 treatments was replicated 10 times at both sites, for a total of 60 treatment plots at each site.

Standardized $(9.5 \times 9.5 \times 1 \mathrm{~cm})$ rough terra cotta tiles were chosen as settling plates $(n=120)$ because their heterogeneous surface enhances species richness and biomass as compared to other artificial substrates (Brock 1979). Tiles were conditioned for 2 mo in a flowthrough seawater tank at the University of Guam (UOG) Marine Laboratory. Small pieces of 'live' rock containing CCA were collected from the Pago Bay reef flat and placed in the tank to propagate growth of CCA. After 2 mo of conditioning, small patches of CCA and filamentous algae were visible on the tiles, at which time they were haphazardly assigned to a site (Piti or Asan) and treatment. The tiles were labeled, digitally photographed, and placed in the field within $72 \mathrm{~h}$.

The square cages, measuring $16 \times 16 \mathrm{~cm}$, were constructed by joining eight $16 \mathrm{~cm}$ pieces of standard $1 / 2$-inch polyvinyl chloride (PVC) electrical pipe with 3way fitting PVC joints. The cages were fitted with Predator Barrier Netting with a mesh size of $1 \mathrm{~cm}$ (N22 Aquatic Eco-Systems), which was secured to the cages with cable ties. The mesh was effective in excluding herbivorous fish and invertebrate herbivores such as sea urchins and large gastropods. The full cages had netting on the top and sides with the base secured to the substrate. Partial cages had a net mesh only on the top, allowing herbivores to enter from the sides while controlling for effects of shading and reduced water flow. Cages were secured to the benthos using ropes and hooks. Weekly maintenance of the experimental plots involved brushing the mesh caging to remove attached algae, securely tightening ropes to the substrate to maintain effective fish exclusion, and noting any losses of treatment effectiveness.

Nutrient-enriched tiles had 2 small bags constructed from fiberglass window screening, each containing $15 \mathrm{~g}$ of Osmocote ${ }^{\circledR}$ slow-release fertilizer (14-14-14 [N$\mathrm{P}-\mathrm{K}])($ Scott's), secured adjacent to the tiles. These bags were changed every 2 wk. This fertilizer is derived from ammonium nitrate, ammonium phosphate, cal- cium phosphate, and potassium sulfate. The total nitrogen $(\mathrm{N})$ equals $14 \%$, consisting of $8.2 \%$ ammonical nitrogen and $5.8 \%$ nitrate nitrogen. Available phosphate $\left(\mathrm{P}_{2} \mathrm{O}_{5}\right)$ equals $14 \%$ and soluble potash $\left(\mathrm{K}_{2} \mathrm{O}\right)$ equals $14 \%$.

On June 27 to 29,2000 , the tiles were transported to the field sites in a cooler filled with seawater to minimize temperature fluctuations. At each site, experimental plots were placed haphazardly along a $50 \mathrm{~m}$ transect, with at least $1 \mathrm{~m}$ separating the plots. Ten replicates of each treatment were placed at both sites. Tiles were secured horizontally to the substrate using a $7: 1$ mixture of cement and plaster. Nutrient bags were tied to a rope that was fixed to the substrate with a $7: 1$ mixture of cement and plaster and placed on opposite sides of the enriched tiles.

Measurement of site parameters. Water samples were collected weekly for measurement of nitrate and nitrite $\left(\mathrm{NO}_{\mathrm{x}}-\mathrm{N}\right)$ and soluble phosphate $\left(\mathrm{PO}_{4}-\mathrm{P}\right)$ concentrations. At each site 4 plots without cages and without fertilizer (ambient seawater), and 4 plots without cages and with fertilizer (enriched seawater) were haphazardly chosen for sampling. For the first 3 sampling dates, acid-washed $100 \mathrm{ml}$ Nalgene bottles were used to collect water samples. The empty bottles were opened approximately $2 \mathrm{~cm}$ above the tiles. For the last 2 collections, $60 \mathrm{ml}$ acid-washed syringes were used; the method was changed in an attempt to obtain a more accurate water-column sample from $2 \mathrm{~cm}$ above the tile surface. Water samples were stored on ice after collection. UOG's Water and Environmental Research Institute performed nutrient analyses. $\mathrm{NO}_{\mathrm{x}}-\mathrm{N}$ and $\mathrm{PO}_{4-}$ $\mathrm{P}$ were measured using a Latchet Flow Injection Analyzer (FIA) using the automated QuikChem Method 31-115-01-3-A for $\mathrm{PO}_{4}$-P and QuikChem Method 31107-04-1-A for $\mathrm{NO}_{\mathrm{X}}-\mathrm{N}$ (Zellweger Analytics, Lachat Instruments). The methods are written for seawater and brackish water. The methods are an FIA implementation of Standard Methods 4500-P using the Ascorbic Acid Chemistry Method and 4500- $\mathrm{NO}_{3}-\mathrm{F}$ using the Cadmium Reduction Method (American Public Health Association 1992). Corresponding quality control standards (100 parts per billion [ppb] $\mathrm{NO}_{3}$ and $100 \mathrm{ppb} \mathrm{PO}_{4}$ ) were run with each analysis to ensure correct calibration. In addition, daily nutrient release from the fertilizer bags was calculated by weighing the remaining fertilizer after 2 wk of exposure (the last bags were exposed for $1 \mathrm{wk}$ ) after drying, then subtracting this from initial fertilizer mass and dividing by days of exposure to calculate mass lost per day. Mean total mass lost of fertilizer, after 2 wk exposure, was $680 \pm 90 \mathrm{mg} \mathrm{d}^{-1}$, yielding an approximate release of $95.2 \mathrm{mg} \mathrm{N} \mathrm{d}^{-1}$ and $95.2 \mathrm{mg} \mathrm{P} \mathrm{d}^{-1}$.

Using a modification of the transect methods of Lewis \& Wainwright (1985), visual censuses of herbi- 


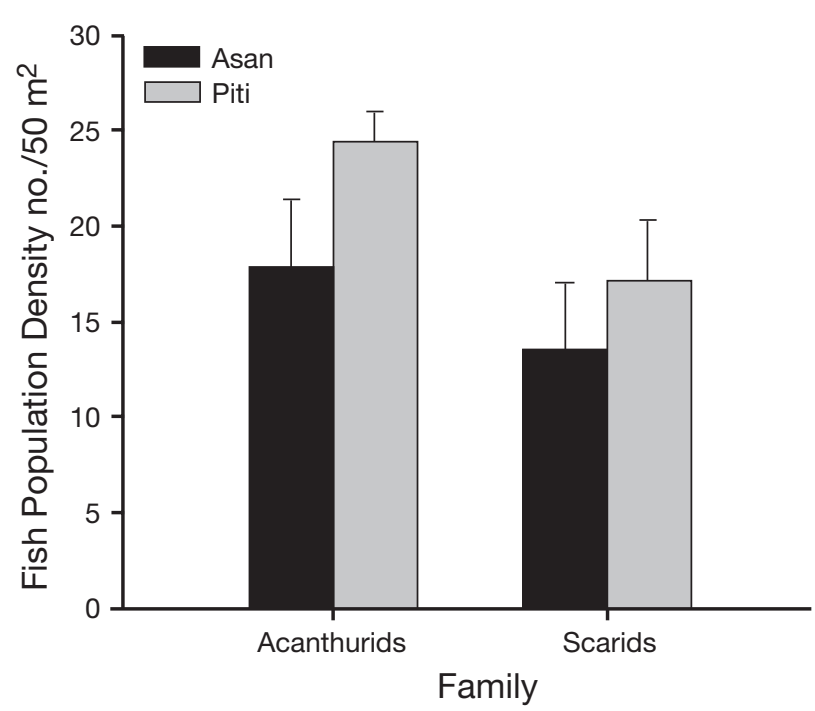

Fig. 1. Mean number $( \pm \mathrm{SE})$ of herbivorous fish $50 \mathrm{~m}^{-2}$ estimated weekly $(n=5)$ at Asan and Piti. No rabbitfishes were encountered during censuses

vorous fish were done weekly between 10:00 and 12:00 h for $5 \mathrm{wk}$ at each site. Parrotfishes and surgeonfishes encountered within $1 \mathrm{~m}$ on either side of the $50 \mathrm{~m}$ experimental site were counted for each site. Two consecutive transect passes were averaged to give counts of ind. $50 \mathrm{~m}^{-2}$. No rabbitfishes were observed inside the area during counts.

Measuring algal biomass, CCA, and sediment. On August 3, 2000, after $5 \mathrm{wk}$ of field manipulation and monitoring, the tiles were collected. The tiles were placed into labeled Ziploc ${ }^{\circledR}$ bags, placed in a cooler, and transported back to the UOG Marine Laboratory.

Upon returning from the field, sediment was gently shaken from each tile into individual collection bags. The sediment was then vacuum-filtered over preweighed glass fiber filters. The filters were dried in a $60^{\circ} \mathrm{C}$ oven for $10 \mathrm{~d}$, and the sediment was weighed on an analytical balance.

After the collection of loose sediment, tiles were placed in a flow-through seawater tank. Over the next $2 \mathrm{~d}$ coral recruits that had settled onto the tiles were counted, and fleshy algae were scraped from the tiles to calculate the algal biomass. Due to the short duration of the field study, macroalgae were not able to reach a height that allowed them to be separated from the turf algae. Therefore, all non-encrusting algae on the tiles were scraped from the tiles onto individually labeled filter papers and dried in a $60^{\circ} \mathrm{C}$ oven for $3 \mathrm{~d}$. Some sediment from the holding tank had gotten entrapped in the algae while the tiles were being processed. To obtain an accurate measurement of algal biomass without confounding it with newly acquired sediment, the ash-free dry mass (AFDM) of the algae was measured. Glass filters with sediment and dried algae were placed in a muffle furnace for $24 \mathrm{~h}$ at $500^{\circ} \mathrm{C}$ in order to burn off the organic material (Brinkhaus 1985). After combustion, the residue was weighed and its mass subtracted from the initial dry mass to yield AFDM of algae (mg).

Each tile was then photographed, using a digital camera, for determining the percentage cover of CCA. Digital photographs of each tile before and after the experiment were downloaded to Sigma Scan Pro 5.0 image analysis software (SPSS Science Software). Areas of CCA were outlined, and the percentage cover was determined. These analyses were done for the tiles $72 \mathrm{~h}$ prior to their placement in the field and following their collection, to determine change in CCA over the course of the experiment.

The coral recruits on the tiles were counted using a dissecting microscope, and in each case the substrate that the corals had settled onto was identified and recorded.

Statistical analyses. The effects of herbivory, nutrients, and site on percentage cover of CCA, AFDM of algae, and dry mass of sediment were analyzed using 3-way analysis of variance (ANOVA). Tukey's honestly significant difference (HSD) method was used to further investigate significant differences among treatments. Bartlett's test of equal variances was used to test for homoscedasticity, and the Shapiro-Wilk test was used to test for normality. The sediment and AFDM of algae data were $\log (x+1)$ transformed so that they would not violate assumptions of ANOVA

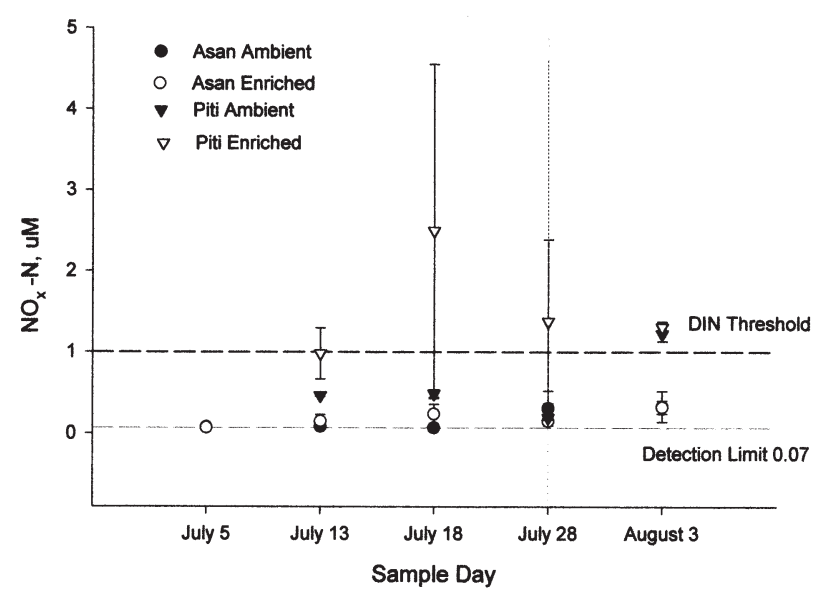

Fig. 2. Mean water-column levels of dissolved $\mathrm{NO}_{\mathrm{x}}-\mathrm{N}( \pm \mathrm{SE})$ over enriched $(\nabla \mathrm{O}, \mathrm{n}=4$, except July $28, \mathrm{n}=3$ ) and ambient $(\boldsymbol{\nabla}, \mathrm{n}=4)$ tiles, collected during field manipulations at Piti ( 4 collection d) and Asan ( 5 collection d). Threshold level of $1.0 \mu \mathrm{M}$ indicates proposed threshold level of dissolved inorganic nitrogen (DIN) on macroalgal growth (Bell 1992, Lapointe 1997). Dashed vertical line on $y$-axis represents change in collection method from bottle to syringe; see 'Materials and methods' for details 
(Zar 1984). Pearson's correlation coefficients were used to examine the degree of association between AFDM of algae and final CCA cover and sediment. Poisson regression was used to determine whether the percentage cover of CCA on the tile was correlated to coral recruitment (Sokal \& Rohlf 1995).

The effects of site, day, and family of fish on counts of herbivorous fishes were analyzed by 3-way ANOVA. Mann Whitney $U$-tests were used to evaluate differences in mean water-column concentration of nutrients. One-tailed tests were used to compare enriched versus ambient levels within sites; 2-tail probabilities were used to compare nutrients between sites. Statistical analyses were performed using Statistix 7 (Analytical Software, Tallahassee, Florida).

\section{RESULTS}

Over the course of the $5 \mathrm{wk}$ experiment, a total of 13 tiles had been compromised and therefore were not used in the final analysis. Four cages dislodged from the substrate, 4 tiles were lost, and damselfish had established territories on 5 of the tiles. Because damselfish are known to cultivate algal gardens, these tiles were not used. Between 8 and 10 replicate tiles for each treatment remained for statistical analyses.

The sites did not differ significantly in herbivore density (Fig. 1; df =1, F= 3.56, $p=0.1321$ ) on any of the days surveyed ( $\mathrm{df}=4, F=1.44, \mathrm{p}=0.3667$ ), nor was there a difference in abundance of the 2 taxa of fish (df $=1, F=4.61, \mathrm{p}=0.0938$ ). Rabbitfish were observed at the sites during the study; however, they were not observed in censuses.

Mean ambient water-column levels of $\mathrm{NO}_{\mathrm{x}}-\mathrm{N}$ were significantly lower than enriched water-column levels at Piti ( $u=77$, df $=16,15, \mathrm{p}=0.045)$ but not at Asan ( $u=150.5, \mathrm{df}=20,19, \mathrm{p}=0.11$ ) (Fig. 2). Mean enriched $\mathrm{NO}_{\mathrm{x}}-\mathrm{N}$ levels at Piti were $1.55 \pm 0.55 \mu \mathrm{M}$; this is above the proposed threshold limit of $1.0 \mu \mathrm{M} \mathrm{NO} \mathrm{N}_{\mathrm{x}} \mathrm{N}$ at which macroalgal blooms are predicted to occur (Bell 1992, Lapointe 1997), whereas mean ambient concentration of $\mathrm{NO}_{\mathrm{x}} \mathrm{-N}$ at Piti was below the threshold limit $(0.59 \pm 0.10 \mu \mathrm{M})$. At Asan, $\mathrm{NO}_{\mathrm{x}}-\mathrm{N}$ levels did not exceed threshold limit in either enriched $(0.19 \pm 0.04 \mu \mathrm{M})$ or ambient $(0.18 \pm 0.06 \mu \mathrm{M})$ plots. Mean ambient levels of $\mathrm{NO}_{\mathrm{x}}-\mathrm{N}$ were significantly higher at Piti than at Asan ( $u$ $=28.5, \mathrm{df}=20,16, \mathrm{p}<0.001)$, as were enriched $\mathrm{NO}_{\mathrm{x}}-\mathrm{N}$ levels $(u=19$, df $=19,15, \mathrm{p}<0.001)$. Piti's close proximity to several rivers could account for its higher ambient level of $\mathrm{NO}_{\mathrm{x}}-\mathrm{N}$.

Mean enriched water-column levels of $\mathrm{PO}_{4}-\mathrm{P}$ were significantly higher than ambient water-column levels at Piti ( $u=72$, df $=16,15, p=0.003)$ (Fig. 3). The mean
$\mathrm{PO}_{4}$-P level of enriched plots at Piti was $0.31 \pm 0.15 \mu \mathrm{M}$ (above the proposed threshold limit of $0.1 \mu \mathrm{M} \mathrm{PO}_{4}-\mathrm{P}_{i}$ Bell 1992, Lapointe 1997), whereas mean ambient levels were below the detection limit of $0.03 \mu \mathrm{M}$. At Asan, the mean water-column $\mathrm{PO}_{4}-\mathrm{P}$ was very near the detection limit $(0.03 \pm 0.0 \mu \mathrm{M})$ for enriched and ambient samples. Mean ambient levels of $\mathrm{PO}_{4}-\mathrm{P}$ were not significantly different between sites $(u=128$, df $=$ $20,16, p=0.06$ ), but enriched plots were significantly higher in $\mathrm{PO}_{4}-\mathrm{P}$ at $\mathrm{Piti}(u=85.5, \mathrm{df}=19,15, \mathrm{p}=0.003)$.

Table 1. Three-way analyses of variance (ANOVAs). Factors were herbivory, nutrients, and site (A) ash-free dry mass (AFDM) of algae, (B) percentage cover of crustose coralline algae (CCA) (final-initial percentage cover) and (C) sediment. Raw data were used for CCA, while data for AFDM of algae and sediment were $\log ($ mean +1$)$ transformed to meet assumptions of ANOVA. Significant differences between treatments were analyzed by Tukey's honestly significant difference (HSD) comparison of means test. Treatments are NC: no cage; C: cage; PC: partial cage; NE: no enrichment; E: enrichment. Bold-face p-values indicate statistically significant results

\begin{tabular}{|c|c|c|c|c|}
\hline Source & df & MS & $F$ & $\mathrm{p}$ \\
\hline \multicolumn{5}{|l|}{ A. AFDM of algae } \\
\hline Herbivory & 2 & 2.094 & 9.09 & $<0.001$ \\
\hline Nutrients & 1 & 0.197 & 0.85 & 0.3581 \\
\hline Site & 1 & 0.028 & 0.12 & 0.7302 \\
\hline Herbivory $\times$ nutrients & 2 & 0.206 & 0.89 & 0.4127 \\
\hline Herbivory $\times$ site & 2 & 0.207 & 0.90 & 0.4111 \\
\hline Nutrient $\times$ site & 1 & 0.112 & 0.49 & 0.4870 \\
\hline Herbivory $\times$ nutrients $\times$ site & 2 & 0.130 & 0.56 & 0.5716 \\
\hline Error & 89 & 0.230 & & \\
\hline \multicolumn{5}{|l|}{ Tukey's HSD test: } \\
\hline \multicolumn{5}{|l|}{ Herbivory $\mathrm{NC}=\mathrm{PC}<\mathrm{C}$} \\
\hline \multicolumn{5}{|l|}{ B. CCA } \\
\hline Herbivory & 2 & 4450.3 & 22.92 & $<0.001$ \\
\hline Nutrients & 1 & 678.671 & 3.5 & 0.0646 \\
\hline Site & 1 & 147.255 & 0.76 & 0.3860 \\
\hline Herbivory $\times$ nutrients & 2 & 412.828 & 2.13 & 0.1249 \\
\hline Herbivory $\times$ site & 2 & 268.436 & 1.38 & 0.2560 \\
\hline Nutrient $\times$ site & 1 & 1586.74 & 8.17 & 0.0052 \\
\hline Herbivory $\times$ nutrients $\times$ site & 2 & 189.228 & 0.97 & 0.3811 \\
\hline Error & 95 & 194.175 & & \\
\hline \multicolumn{5}{|l|}{ Tukey's HSD test: } \\
\hline \multicolumn{5}{|l|}{ Herbivory $-\mathrm{NC}=\mathrm{PC}>\mathrm{C}$} \\
\hline \multicolumn{5}{|c|}{ Nutrients $\times$ site - Asan, NE $=E$; Piti, NE $>E$} \\
\hline \multicolumn{5}{|l|}{ C. Sediment } \\
\hline Herbivory & 2 & 7.178 & 42.38 & $<0.001$ \\
\hline Nutrients & 1 & 0.387 & 2.29 & 0.1339 \\
\hline Site & 1 & 0.611 & 3.61 & 0.0607 \\
\hline Herbivory $\times$ nutrients & 2 & 0.078 & 0.46 & 0.6325 \\
\hline Herbivory $\times$ site & 2 & 0.614 & 3.62 & 0.0306 \\
\hline Nutrient $\times$ site & 1 & 0.253 & 1.49 & 0.2249 \\
\hline Herbivory $\times$ nutrients $\times$ site & 2 & 0.063 & 0.37 & 0.6921 \\
\hline Error & 92 & 0.169 & & \\
\hline \multicolumn{5}{|l|}{ Tukey's HSD test: } \\
\hline \multicolumn{5}{|l|}{ Herbivory - NC $=\mathrm{PC}<\mathrm{C}$} \\
\hline \multicolumn{5}{|c|}{ Herbivory $\times$ site - Asan, $\mathrm{NC}=\mathrm{PC}<\mathrm{C}_{i}$ Piti, NC $=\mathrm{PC}<\mathrm{C}$} \\
\hline
\end{tabular}




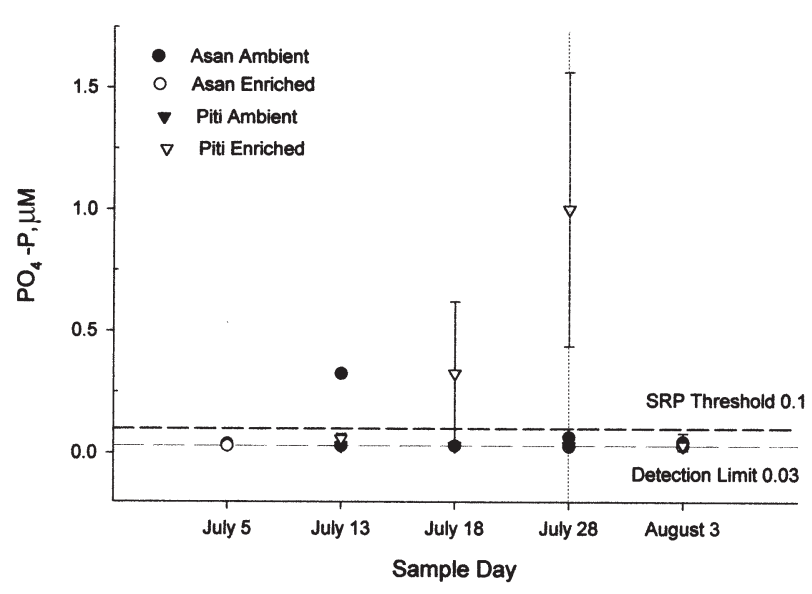

Fig. 3. Mean water-column levels of soluble reactive phosphate (SRP) $( \pm \mathrm{SE})$ over enriched $(\nabla \mathrm{O}, \mathrm{n}=4$, except July 28 , $\mathrm{n}=3$ ) and ambient $(\boldsymbol{\nabla}, \mathrm{n}=4)$ tiles, collected during field manipulations at Piti (4 collection d) and Asan (5 collection d). Threshold level of $0.1 \mu \mathrm{M}$ indicates proposed threshold level of SRP on macroalgal growth (Bell 1992, Lapointe 1997). Dashed vertical line down $y$-axis represents change in collection method from bottle to syringe; see 'Materials and methods' for details

Herbivore pressure significantly decreased AFDM of algae (Table $1 \mathrm{~A})$; it was nearly double on caged tiles (30.43 \pm 3.99$) \mathrm{mg}$ compared to uncaged tiles $(13.58 \pm$ $2.47 \mathrm{mg})$ and partially caged tiles $(17.47 \pm 5.31 \mathrm{mg})$ (Fig. 4). Nutrients and site had no significant effects on AFDM of algae.

In contrast, there was a significant positive effect of herbivory on percentage change of CCA (Table 1B, Fig. 5). Change in cover of CCA increased $50 \%$ less on caged tiles $(14.33 \pm 1.81 \%)$ relative to uncaged tiles $(33.92 \pm 2.96 \%)$ and partially caged tiles $(29.99 \pm$ $2.34 \%$ ). There was also a significant interaction between nutrients and site. The nutrient enrichment treatment significantly decreased change in surface cover of CCA at Piti (MS = 1953.39, df $=1, F=14.41, \mathrm{p}=$ 0.004 ) but not at Asan (MS $=94.97, \mathrm{df}=1, F=0.55, \mathrm{p}=$ $0.464)$. Final cover of CCA was negatively correlated with AFDM of algae $(\mathrm{r}=-0.486, \mathrm{p}<0.001)$. Lithoporella melobesioides was identified as one of the dominant CCA species on the tiles. This is an early successional species with thin conceptacles. Peyssonnelia spp. were also found in small patches on the tiles along with small crusts of some late successional species such as Paragoniolithon conicum, which was seen overgrowing the early successional species (observation and identification by R. S. Steneck, February 2001).

Herbivore exclusion cages significantly increased sediment load (Table 1C). Like algal biomass, sediment mass was significantly greater on caged tiles $(3.43 \pm 0.55 \mathrm{~g})$ than on uncaged tiles $(0.65 \pm 0.15 \mathrm{~g})$ and partially caged tiles $(0.47 \pm 0.07 \mathrm{~g})$, which did not differ from each other (Fig. 6). There was a significant interaction between herbivory and site, although when separated by site herbivory was significant at both Piti $(p<0.001)$ and Asan $(p<0.001)$. There was no significant effect of nutrients on sediment (Table 1C). Sediment load was positively correlated with algal biomass $(\mathrm{r}=0.2302, \mathrm{p}=0.0219)$, suggesting algal retention of sediment; hydrographic effects of cages may have also contributed to increased sediment.

The mass coral spawning, during the week of July 16,2000 , occurred $3 \mathrm{wk}$ after the experimental plots were set out on the reefs, and the tiles remained in the field for an additional 2 wk after spawning. The recruitment density of corals was low $\left(11.4 \mathrm{~m}^{-2}\right)$, with only 11 recruits seen. No patterns of preferential settlement in different caging or nutrient treatments were observed (Table 2). Eight of the 11 recruits were settled on patches of CCA. The mean final percentage cover of CCA on tiles with coral recruits $(41.0 \pm 5.1 \%)$ was marginally greater than mean final percentage cover on all other tiles $(31.8 \pm 1.7 \%, T=1.9, \mathrm{df}=104$, $p=0.06$ ). Poisson regression of coral recruits versus final cover of CCA showed that CCA had a positive influence on the distribution of recruits, but the strength of the relationship was not strong enough to be significant (slope of coefficient $=0.02486$, coefficient $/ \mathrm{SE}=1.78, \mathrm{p}=0.0745$ ).

\section{DISCUSSION}

The impetus for this study was to examine how herbivory and nutrients influence the colonization of

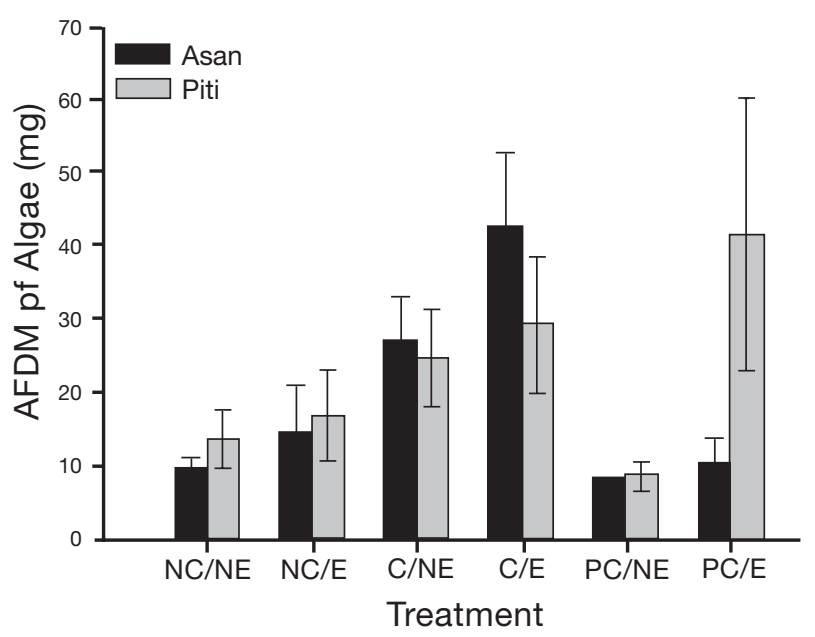

Fig. 4. Mean ash-free dry mass (AFDM) of algae $(\mathrm{mg})( \pm \mathrm{SE})$ in each of the 6 treatments at Asan and Piti at the end of field manipulations. Columns correspond to a treatment: no cage, not enriched (NC/NE), no cage, enriched (NC/E), cage, not enriched $(\mathrm{C} / \mathrm{NE})$, cage, enriched $(\mathrm{C} / \mathrm{E})$, partial cage, not enriched (PC/NE), partial cage, enriched (PC/E) 


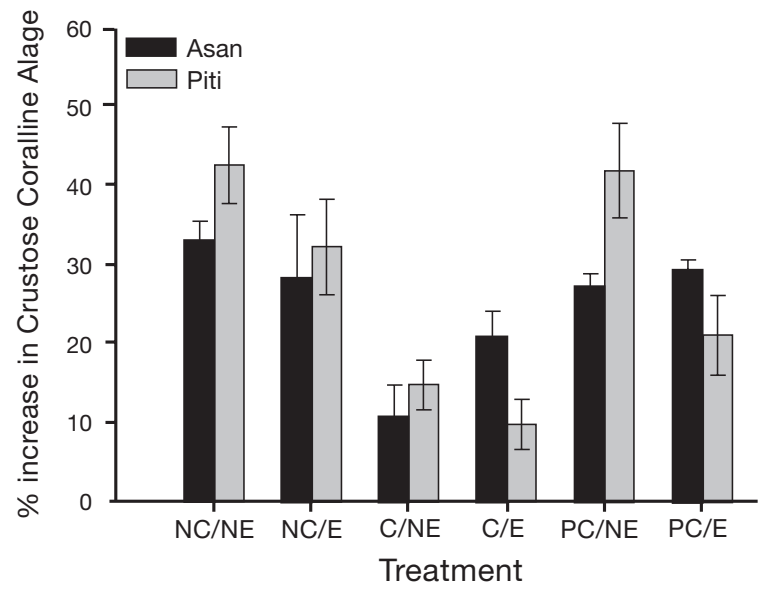

Fig. 5. Mean percentage cover of crustose coralline algae (CCA) $( \pm$ SE) on surface of tiles (final-initial percentage cover of CCA) in each of the 6 treatments at Asan and Piti at the end of field manipulations. See Fig. 4 for treatment abbreviations

fleshy algae and CCA to open substratum. Competition for space in reef communities is intense (Connell 1978, Littler \& Littler 1984), and thus the organisms that initially colonize new and open substrata may play a key role in influencing the structure of reef communities (Done 1992). Macroalgae, in particular, can outcompete corals and pre-empt further coral settlement (Done 1992, Hughes 1994, Littler \& Littler 1997), whereas CCA may have the opposite effect. CCA contain chemical cues that can facilitate settlement and metamorphosis of some species of corals (Morse \& Morse 1996, Heyward \& Negri 1999) and thus could promote coral recruitment. The prevailing view is that herbivory maintains low algal biomass (Done 1992, Hughes 1994, Littler \& Littler 1997, McCook 1999). The results of this study demonstrate that herbivory had a significant effect on algal biomass, CCA, and sediment load, whereas nutrients did not have a significant effect on algal biomass or sediment but had a significant negative effect on CCA at Piti.

Significant effects of caging on AFDM of fleshy algae were such that full cages had more biomass than partial and open cages. These results confirmed previous experiments and field observations, which have shown that in the presence of significant herbivory, algal biomass is minimized (Carpenter 1986, Lewis 1986, Steneck 1988, Hughes 1994, Miller et al. 1999, Smith et al. 2001, Thacker et al. 2001). On reefs, algal biomass is kept in early successional stages by grazers (Carpenter 1986). Early successional species such as turf algae are typically better adapted to nutrient uptake (Littler et al. 1983) and are more palatable and less defended than macroalgae (Steneck 1988, Hay 1991). Therefore, a reduction of herbivorous fishes can promote growth of macroalgae over the more palat-

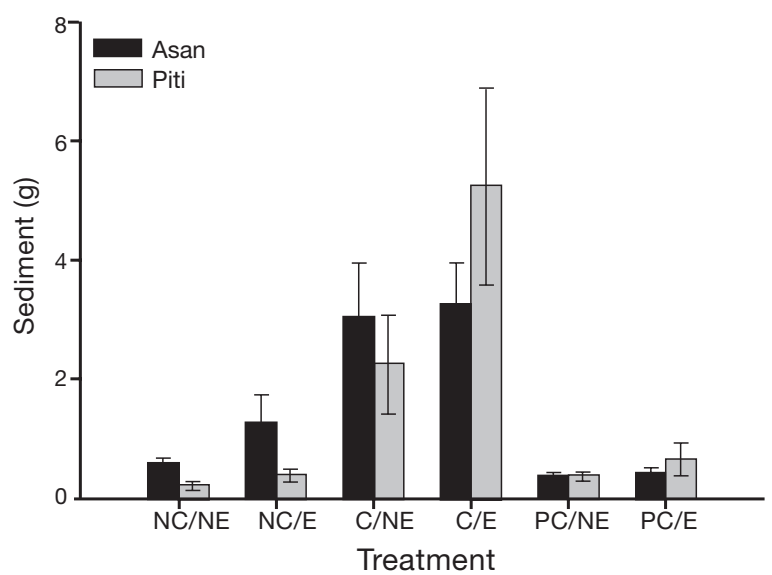

Fig. 6. Mean dry mass $(g)$ of sediment $( \pm S E)$ in each of the 6 treatments at Asan and Piti at the end of field manipulations. See Fig. 4 for treatment abbreviations

able turf algae. Because many species of macroalgae have inherent defenses to herbivores, a shift to a persistent alternative macroalgal stable state can ensue (Hatcher 1984, Done 1992, Knowlton 1992, Thacker et al. 2001), to the detriment of coral recruitment and survivorship (Birkeland 1977, Lewis 1986).

Mean enrichment levels of $\mathrm{NO}_{\mathrm{x}}-\mathrm{N}$ and $\mathrm{PO}_{4}$-P were above the proposed threshold limits postulated to lead to rapid macroalgal growth (Bell 1992, Lapointe et al. 1997, Lapointe 1999) at Piti. Yet, these results do not suggest that 'threshold' level enrichment enhanced fleshy algal biomass at Piti. Our findings, in support of similar studies, indicate that fleshy algal growth was not significantly increased by nutrient input, unlike the marked

Table 2. Number of coral recruits settled onto tiles by treatment. Final percentage cover of CCA on tiles coral recruits settled onto are recorded in the columns by site. No tile had more than 1 coral recruit

\begin{tabular}{|c|c|c|c|c|}
\hline \multirow[t]{2}{*}{ Treatment } & \multicolumn{2}{|c|}{ Asan } & \multicolumn{2}{|c|}{ Piti } \\
\hline & $\begin{array}{l}\text { Coral } \\
\text { recruits }\end{array}$ & $\begin{array}{l}\% \text { Cover } \\
\text { of CCA }\end{array}$ & $\begin{array}{l}\text { Coral } \\
\text { recruits }\end{array}$ & $\begin{array}{l}\% \text { Cover } \\
\text { of CCA }\end{array}$ \\
\hline No cage, no enrichment & at 1 & 51 & - & - \\
\hline No cage, enriched & - & - & - & - \\
\hline Cage, no enrichment & 2 & $\begin{array}{l}24 \\
17\end{array}$ & - & - \\
\hline Cage, enriched & 2 & $\begin{array}{l}26 \\
34\end{array}$ & & \\
\hline $\begin{array}{l}\text { Partial cage, } \\
\text { no enrichment }\end{array}$ & - & - & 5 & $\begin{array}{l}34 \\
58 \\
47 \\
62 \\
68\end{array}$ \\
\hline $\begin{array}{l}\text { Partial cage, } \\
\text { enrichment }\end{array}$ & - & - & 1 & 28 \\
\hline
\end{tabular}


effect herbivore pressure had on algal growth (Hatcher \& Larkum 1983, Larkum \& Koop 1997, Miller et al. 1999, Thacker et al. 2001, but see Smith et al. 2001).

However, the negative effect of nutrient enrichment on CCA cover at Piti is compelling. The few empirical studies that have looked at the effects of nutrients on CCA have shown either no effect of nutrient enrichment on CCA (Miller et al. 1999, Wilder 2000) or an increase in calcified algae with enrichment (Smith et al. 2001). The significant negative effect of nutrientenriched plots on CCA at Piti corresponded with the mean water-column concentrations of enriched plots, being above the proposed threshold limit of $1.0 \mu \mathrm{M}$ $\mathrm{NO}_{\mathrm{x}}-\mathrm{N}$ and $0.1 \mu \mathrm{M} \mathrm{PO}_{4}-\mathrm{P}$ (Bell 1992, Lapointe 1997). Field observations by Björk et al. (1995) measuring cover of CCA in relation to decreasing distance to a sewage outfall showed that mean water concentrations of phosphate levels of 0.2 to $0.4 \mu \mathrm{M}$ were sufficient in significantly reducing cover of CCA. Further laboratory study by Björk et al. (1995) found the addition of phosphate to CCA caused a significant decrease in growth and calcification, whereas nitrate and ammonium had no significant effect on CCA growth. High levels of phosphate have also been shown to inhibit calcite crystal growth in hard coral (Kinsey \& Davies 1979), hence decreasing calcification and coral growth (Smith 1984, Tomascik \& Sander 1987, Green et al. 1997). Therefore, these results lend support to CCA, which are like corals in that they are both calcified, favoring low levels of nutrients, especially phosphate.

Nutrient levels are 1 factor influencing the productivity potential of algae; 2 other important factors are light and water flow (Steneck \& Dethier 1994). Although the experiment did not directly measure light, partial cages controlled for light obstruction, and no significant effect due to caging was found. Carpenter \& Williams (1993) found water flow to strongly influence algal turf canopy, and they suggest it to be a better predictor of algal dominance then nutrients. Littler \& Littler (1984) propose that CCA favors high wave energy primarily because of increased advection of nutrients to CCA. Our results suggest that nutrients may not favor CCA growth, and that, like corals, CCA may optimally grow in high herbivory or high wave energy (flow) and low nutrient (particularly low phosphate) environments.

As expected, tiles exposed to fish grazing had a greater increase in CCA cover. Previous studies showed that increased herbivory promoted CCA growth (Lewis 1986, Steneck \& Dethier 1994, Steneck 1997, Miller et al. 1999). Unlike fleshy algae, CCA can resist grazing due to their inherent toughness (Pitlik \& Paul 1997). Previous studies have also shown algal turf to trap sediment, thus increasing sediment on substrata, limiting survivorship of CCA and corals (Rogers
1990, McClanahan 1997, Steneck 1997, Fabricius \& De'ath 2001, Smith et al. 2001). Tiles that were caged had increased sediment, which was positively correlated to increased algal biomass. Sediment, like algal biomass, was negatively correlated with CCA. Sediment has been shown to smother CCA, creating anoxic conditions that decrease the survivorship and recruitment of CCA (Steneck 1997, Figueiredo \& Steneck 2000, Fabricius \& De'ath 2001); however, Figueiredo \& Steneck (2000) have shown a positive correlation of CCA and macroalgae, suggesting CCA can survive light limitation in the understory of macroalgae. Water flow may also have influenced these results; open cages may have provided greater flow rates, decreasing sediment accumulation onto tiles, thus enhancing survival of CCA.

Herbivory is important not only in maintaining the survivorship of CCA but also the survivorship and recruitment of corals (Birkeland 1977, Edmunds \& Carpenter 2001). Herbivory creates frequent disturbances on reefs (Steneck \& Dethier 1994), reducing spatial competition of coral recruits with benthic algae (Birkeland 1977), and promotes CCA growth (Sala et al. 1998), which can favor coral settlement (Morse \& Morse 1996, Morse et al. 1996, Heyward \& Negri 1999). Unfortunately, the low number of recruits to tiles did not give us enough power to test the hypothesis that recruits were actively settling on CCA versus bare substratum. Decreasing cover of living coral along with declining fish abundance suggest that coral recruitment levels may be decreasing on Guam in relation to decreasing numbers of herbivores (Birkeland 1997b).

The clear effect that herbivory had on fleshy algae and CCA over the short time period of $5 \mathrm{wk}$ in this study affirms that reef fish can have a critical role in structuring the benthic community. The results suggest that herbivory is the key factor determining colonization and survival of fleshy algae and CCA to newly exposed substratum. These results, along with previous findings (Hatcher 1983, Lewis 1986, Steneck 1988, Hughes 1994, Steneck 1997, Sala et al. 1998) indicate that herbivory limits algal biomass, thereby promoting growth of CCA and potentially coral recruitment (Birkeland 1977, Steneck 1997, Edmunds \& Carpenter 2001). Because overfishing threatens reef succession following disturbance, which can lead to a permanent phase shift to a macroalgae-dominated community, the establishment of fishing regulations to protect vulnerable herbivorous fish populations along with the establishment of Marine Protected Areas is critical in maintaining reef health and biodiversity.

Acknowledgements. This research was submitted in partial fulfillment of the Master of Science degree to S.A.B. at University of Guam. We thank the thesis committee members - 
Lee Yudin, Bob Richmond, and Chris Lobban — for valuable comments that helped improve the manuscript. We thank Sonia Shjegstad, Ilsa Kuffner, Chris Bassler, Brent Womersley, Melani Montano, Butch Irish, and Seth Gogo for their generous assistance with the field and laboratory work. We also thank Rick Wood and Lucrina Concepcion of the University of Guam Water and Environmental Research Institute for nutrient analyses and Bob Steneck for identification of crustose coralline algae. Finally, we would like to thank Steven Vollmer, Bob Steneck, and the contributing editor, Charles Birkeland, and the 4 anonymous reviewers for their critiques and suggestions that helped improve the manuscript. This is contribution no. 30 of the Ecology and Oceanography of Harmful Algal Blooms (ECOHAB) program and contribution no. 460 of the UOG Marine Laboratory. Although the research described in this article has been funded wholly or in part by the US Environmental Protection Agency through grant number R82-6220, it has not been subjected to the Agency's required peer and policy review and therefore does not necessarily reflect the views of the Agency, and no official endorsement should be inferred.

\section{LITERATURE CITED}

Adey WH (1998) Coral reefs: algal structured and mediated ecosystems in shallow, turbulent, alkaline waters. J Phycol 34:393-406

American Public Health Association (1992) Standard methods for the examination of water and wastewater, 18th edn. American Public Health Association, Washington, DC

Aronson RB, Precht WF (2000) Herbivory and algal dynamics on the coral reef at Discovery Bay, Jamaica. Limnol Oceanogr 45:251-255

Bell PRF (1992) Eutrophication and coral reefs: some examples in the Great Barrier Reef lagoon. Water Res 26: 553-568

Birkeland CE (1977) The importance of rate of biomass accumulation in early successional stages of benthic communities to the survival of coral recruits. Proc 3rd Int Coral Reef Symp 1:15-21

Birkeland CE (1997a) Introduction. In: Birkeland CE (ed) Life and death of coral reefs. Chapman \& Hall, New York, p 1-10

Birkeland CE (1997b) Status of coral reefs in the Marianas. In: Grigg RW, Birkeland C (eds) Status of coral reefs in the Pacific. Sea Grant College Program, University of Hawaii, p 144

Björk M, Mohammed SM, Björklund M, Semesi A (1995) Coralline algae, important coral-reef builders threatened by pollution. Ambio 24:502-505

Brinkhaus BH (1985) Growth patterns and rates. In: Littler M, Littler D (eds) Handbook of phycological method, ecological field methods: macroalgae. Cambridge University Press, Cambridge, p 461-478

Brock RE (1979) An experimental study on the effects of grazing by parrotfishes and role of refuges in benthic community structure. Mar Biol 51:365-389

Brown BE (1997) Disturbance to reefs in recent times. In: Birkeland CE (ed) Life and death of coral reefs. Chapman \& Hall, New York, p 370-378

Carpenter RC (1986) Partitioning herbivory and its effects on coral reef algal communities. Ecol Mongr 56:345-363

Carpenter RC, Williams SL (1993) Effects of algal turf canopy height and microscale substratum topography on profiles of flow speed in a coral forereef environment. Limnol Oceanogr 38:687-694
Connell JH (1978) Diversity in tropical rainforests and coral reefs. Science 199:1302-1309

Connell JH (1997) Disturbance and recovery of coral assemblages. Coral Reefs 16:S101-S113

Dight IJ, Scherl LM (1997) The International Coral Reef Initiative (ICRI): global priorities for the conservation and management of coral reefs and the need for partnerships. Coral Reefs 16:S139-S147

Done TJ (1992) Phase shifts in coral ref communities and their ecological significance. Hydrobiologia 247:21-132

Edmunds PJ, Carpenter RC (2001) Recovery of Diadema antillarum reduces macroalgal cover and increases abundance of juvenile corals on a Caribbean reef. Proc Natl Acad Sci USA 98:5067-5071

Fabricius K, De'ath G (2001) Environmental factors associated with the spatial distribution of crustose coralline algae on the Great Barrier Reef. Coral Reefs 19:303-309

Figueiredo MA, Steneck RS (2000) Floristic and ecological studies of crustose coralline algae on Brazil's Abrolhos Reefs. Proc 9th Int Coral Reef Symp, p 123 (Abstract)

Green AL, Birkeland CE, Randall RH, Smith BD, Wilkins S (1997) 78 years of coral reef degradation in Pago Pago Harbor: a quantitative record. Proc 8th Int Coral Reef Symp 2:1883-1888

Grigg RW (1983) Community structure, succession and development of coral reefs in Hawaii. Mar Ecol Prog Ser 11: $1-14$

Hatcher BG (1983) Grazing in coral reef ecosystems. In: Barnes DJ (ed) Perspectives on coral reefs. Brian Clouster Publisher for Aust Inst Mar Sci, ACT Manuka, Australia, p 164-179

Hatcher BG (1984) A maritime accident provides evidence for alternate stable states in benthic communities on coral reefs. Coral Reefs 3:199-204.

Hatcher BG, Larkum AWD (1983) An experimental analysis of factors controlling the standing crop of the epilithic algal community on a coral reef. J Exp Mar Biol Ecol 69: $61-84$

Hay ME (1984) Predictable spatial escapes from herbivory: how do these affect the evolution of herbivore resistance in tropical marine communities? Oecologia 64:396-407

Hay ME (1991) Fish-seaweed interactions on coral reefs: effects of herbivorous fishes and adaptation of their prey. In: PF Sale (ed) The ecology of reef fish. Meade Press, San Diego, p 96-117

Heyward AJ, Negri AP (1999) Natural inducers for coral larval metamorphosis. Coral Reefs 18:273-279

Hixon MA, Brostoff WN (1996) Succession and herbivory. Effects of differential fish grazing on Hawaiian coral-reef algae. Ecol Monogr 66:67-90

Hughes TP (1994) Catastrophes, phase shifts, and large-scale degradation of a Caribbean coral reef. Science 265: $1547-1551$

Hughes TP, Szmant AM, Steneck R, Carpenter R, Miller S (1999) Algal bloom on coral reefs: what are the causes? Limnol Oceanogr 44:1583-1586

Hunter CL, Evans CW (1995) Coral reefs in Kaneohe Bay, Hawaii: two centuries of western influence and two decades of data. Bull Mar Sci 57:501-515

Jackson JBC (1992) Pleistocene perspectives on coral reef community structure. Am Zool 32:719-731

Johnson CR, Sutton DC (1994) Bacteria on the surface of the crustose coralline algae induce metamorphosis of the crown-of-thorns starfish Acanthaster planci. Mar Biol 120: 305-310

Kaehler S, Williams GA (1997) Do factors influencing recruitment ultimately determine the distribution and abun- 
dance of encrusting algae on seasonal tropical shores? Mar Ecol Prog Ser 156:87-96

Kinsey DW, Davies PJ (1979) Effects of elevated nitrogen and phosphorus on coral-reef growth. Limnol Oceanogr 24: 935-940

Knowlton N (1992) Thresholds and multiple stable states in coral reef community dynamics. Am Zool 32:674-682

Lapointe BE (1997) Nutrient thresholds for bottom-up control of macroalgal blooms on coral reefs in Jamaica and southeast Florida. Limnol Oceanogr 42:119-1131

Lapointe EB (1999) Simultaneous top-down and bottom-up forces control macroalgal blooms on coral reefs (reply to the comment by Hughes et al.). Limnol Oceanogr 44: 1586-1592

Lapointe BE, Littler MM, Littler DS (1997) Macroalgal overgrowth of fringing coral reefs at Discovery Bay, Jamaica: bottom-up versus top-down control. Proc 8th Int Coral Reef Symp 1:927-932

Larkum AWD, Koop K (1997) ENCORE, algal productivity and possible pardigm shifts. Proc 8th Int Coral Reef Symp $1: 881-884$

Lasker HR, Kim K (1996) Larval development and settlement behavior of the gorgonian coral Plexura kuna. J Exp Mar Biol Ecol 207:167-175

Lewis SM (1986) The role of the herbivorous fishes in the organization of a Caribbean reef community. Ecol Monogr 56:183-200

Lewis SM, Wainwright PC (1985) Herbivore abundance and grazing intensity on a Caribbean coral reef. J Exp Mar Biol Ecol 87:215-228

Lewontin RC (1969) The meaning of stability. Brookhaven Symp Biol 22:13-24

Littler MM, Littler DS (1984) Models of tropical reef biogenesis: the contribution of algae. Prog Phycol Res 3:322-365

Littler MM, Littler DS (1997) Disease-induced mass mortality of crustose coralline algae on coral reefs provides rationale for the conservation of herbivorous fish stocks. Proc 8th Int Coral Reef Symp 1:719-724

Littler MM, Taylor PR, Littler DS (1983) Algal resistance to herbivory on a Carribean barrier reef. Coral Reefs 2:111-118

McClanahan TR (1997) Primary succession of coral reef algae: differing patterns on fished versus unfished reefs. J Exp Mar Biol Ecol 218:77-102

McCook LJ (1999) Macroalgae, nutrients and phase shifts on coral reefs: scientific issues and management consequences for the Great Barrier Reef. Coral Reefs 18:357-367

Miller MW, Hay ME, Miller SL, Malone D, Sotka EE, Szmant AM (1999) Effect of nutrients versus herbivores on reef algae: a new method for manipulating nutrients on coral reefs. Limnol Oceanogr 44:33-47

Morse ANC, Morse DE (1996) Flypapers for coral and other planktonic larvae. BioScience 46:254-262

Morse ANC, Iwao K, Baba M, Shimoike K, Hayashibara T, Omori M (1996) An ancient chemosensory mechanism brings new life to corals. Biol Bull 191:149-154

Pitlik TJ, Paul VJ (1997) Effects of toughness, calcite level, and chemistry of crustose coralline algae (Rhodophyta: Corallineales) on grazing by the parrotfish Chlorurus sordidus. Proc 8th Int Coral Reef Symp 1:701-706

Editorial responsibility: Charles Birkeland (Contributing Editor), Honolulu, Hawaii, USA
Richmond RH (1997) Reproduction and recruitment in corals: critical links in the persistence of reefs. In: CE Birkeland (ed) Life and death of coral reefs. Chapman \& Hall, New York, p 175-197

Rogers CS (1990) Responses of coral reefs and reef organisms to sedimentation. Mar Ecol Prog Ser 62:185-202

Sala E, Bourdouresque CF, Harmelin-Vivien M (1998) Fishing, trophic cascades, and the structure of algal assemblages: evaluation of an old but untested paradigm. Oikos 82:425-439

Slattery M, Hines GA, Starmer J, Paul VJ (1999) Chemical signals in gametogenesis, spawning, and larval settlement and defense of soft coral Sinularia polydactyla. Coral Reefs 18:75-84

Smith JE, Smith CM, Hunter CL (2001) An experimental analysis of the effects of herbivory and nutrient enrichment on benthic community dynamics on a Hawaiian reef. Coral Reefs 19:332-342

Smith SV (1984) Phosphorus versus nitrogen limitation in the marine environment. Limnol Oceanogr 29:1149-1160

Smith SV, Kimmerer WJ, Laws EA, Brock RE, Walsh TW (1981) Kanehoe Bay sewage diversion experiment: perspectives on ecosystem responses to nutritional perturbation. Pac Sci 35:279-385

Sokal RR, Rohlf FJ (1995) Biometry, 3rd edn. WH Freeman, New York

Steele MA (1996) Effects of predators on reef fishes: separating cage artifacts from the effects of predation. J Exp Mar Biol Ecol 198:249-267

Steneck RS (1988) Herbivory on coral reefs: a synthesis. Proc 6th Int Coral Reef Symp 1:37-49

Steneck RS (1997) Crustose corallines, other algal functional groups, herbivores and sediments: complex interactions along reef productivity gradients. Proc 8th Int Coral Reef Symp 1:695-700

Steneck RS, Dethier MN (1994) A functional group approach to the structure of algal-dominated communities. Oikos 69:476-498

Stimson J, Larned ST, Conklin E (2001) Effects of herbivory, nutrient levels, and introduced algae on the distribution and abundance of the invasive macroalga Dictyosphaeria cavernosa in Kaneohe Bay, Hawaii. Coral Reefs 19: 343-357

Sutherland JP (1974) Multiple stable points in natural communities. Am Nat 108:859-873

Szmant AM (1997) Nutrient effects on coral reefs: a hypothesis on the importance of topographic and trophic complexity to reef nutrient dynamics. Proc 8th Int Coral Reef Symp 2:1527-1532

Thacker RW, Ginsburg DW, Paul VJ (2001) Effects of herbivore exclusion and nutrient enrichment on coral reef macroalgae and cyanobacteria. Coral Reefs 19:318-329

Tomascik T, Sander F (1987) Effects of eutrophication on reefbuilding corals. I. Growth rate of the reef building coral Montastrea annularis. Mar Biol 94:77-94

Wilder RM (2000) Is herbivory the primary structuring force of coral reef algal communities? Proc 9th Int Coral Reef Symp 126 (Abstract)

Zar JH (1984) Biostatistical analysis, 2nd edn. Prentice Hall, Englewood Cliffs, NJ

Submitted: May 16, 2001; Accepted: October 17, 2001

Proofs received from author(s): April 10, 2002 